\title{
Risk Analysis of Combustion Failure in Gas Turbine Start Process in PLTGU Unit PT.X
}

\author{
Muhammad Syaifuddin Zuhdi ${ }^{1}$ and Mokh. Suef ${ }^{1}$
}

\begin{abstract}
The peaker power plant is a power plant that is operated when the network is at peak load. Being a peaker power plant has an impact more often start- stop for operation of gas turbine. So, the readiness of the gas turbine to start any time is the core business of the peaker power plant. But in reality, start failure still occurs in the generating unit. Start failure can be caused by combustion failure. In 2017 and 2018 years, there was a start failure caused by combustion system failure total 10 out of 19 cases internal start failure. A lot of disadvantages of start failure for the company like very much loss of potential production revenue, loss of fuel consumption, electricity usage for supporting equipment, materials of gas turbine, failure to achieve KPI's company, decrease in customer satisfaction and much more. So, it must be minimized or eliminated. Until now, maintenance for start failure still corrective maintenance. Corrective maintenance is an unscheduled, unpredictable, unplanned or unprogrammed maintenance action based on an event at a certain time so the potential loss of company's income large. One effort to reduce corrective maintenance activities with preventive maintenance. However, to do preventive maintenance, it is necessary to conduct in-depth studies and analysis so that preventive maintenance is carried out effectively and on target. For this reason a risk analysis of the combustion failure with Failure Mode and Effects Analysis (FMEA) method need to do, so the preventive maintenance steps can be obtained to mitigate the risk of start failure in gas turbine power plant. From the result of FMEA, there are two extreme risk from combustor system, igniter and fuel valves. So, preventive maintenance applied to them. It can provide a large potential revenue for industry and company reputation.
\end{abstract}

Keywords- Combustion Failure, Gas Turbine, Failure Mode and Effects Analysis (FMEA), Preventive Maintenance.

\section{INTRODUCTION}

PT. $\mathrm{X}$ is one of the company that operate and maintain power plant unit in Indonesia. In Gresik plant, PT. X have combine cycle gas and steam power plant (PLTGU) that was operate since 1993. In the first operation, this unit as a baseload power plant. But now as a peaker power plant because of there are some power plant more efficient than in Gresik plant. The problem become a peaker power plant is more frequent to start and stop for this power plant. So the readiness of the power plant unit to be asked to start or operate at any time is the main demand of the peaker power plant.

${ }^{1}$ Muhammad Syaifuddin Zuhdi and Mokh. Suef are with Departement of Management Technology, Institut Teknologi Sepuluh Nopember, Indonesia. Email: zuhdibeji@gmail.com; m.suef@ie.its.ac.id.
In productivity perspective for power plant, there are five kinds of key performance indicator (KPI) from customers[1]. They are Capacity Factor (CF), Scheduled Outage Factor (SOF), Equivalent Force Outage Rate (EFOR), Equivalent Availability Factor (EAF) and Planning Operation Factor (POF). If the power plant not ready to start, it will decrease the value of EAF and increase the value of EFOR and also if the power plant start failure. So it has an impact on the decline in power plant's KPI.

Start failures often occurs in gas turbines as shown in Figure 1. In 2018, there were 32 start failures and 9 were caused by combustion failures. As can be seen in Figure 2, combustion failure is the second most common cause after low gas supply pressure. For this reason, it must be control.

There are disadvantages in financial and nonfinancial when start failure occurs in power plant. For financial disadvantages, the company will lost potential production income up to Rp. 2,326,500,000,000, - in 2018, fuel losses, electricity usage losses for supporting equipment up to Rp. 13,669,368.30., Equipment and material loss of power plant and uman resources overtime. For non-financial losses, like a decrease in power plant performance indicators, in this case the value of EAF and EFOR so that the company's KPI (Key Performance Indicator) is not reach and a decrease in external customer satisfaction and company image.

For this reason, it necessary to analyze the combustion failure at the start process of the gas turbine using the FMEA method. From the results of this analysis we will get the sources of failures, causes and solutions to minimize these failures. So that the combustion failure in the gas turbine unit can be minimized or eliminated. In addition, the results of this analysis to give recommendation of effective preventive maintenance foor company to minimize combustion failure.

The purpose of this research is to identify the cause of the combustion failure of the gas turbine start in PT. X, analyzing the risk of combustion failure by using the Failure Mode and Effect Analysis (FMEA) method and determining what steps for preventive maintenance to mitigate the risk of combustion failure in a gas turbine.

\section{LITERATURE REVIEW}

\section{A. Gas Turbine}

Gas turbine is the plant that produce large amounts of energy based on their size and weight[2]. Called as a gas 
turbine because the turbine is driven by hot gas from combustion. The simplest gas turbine system consists of three main components: compressor, combustor and turbine[3]. The selection of power plant unit using gas turbine have advantages and disadvantages. Some advantages if using a gas turbine are first, does not require a large place. This is because the number of component in a gas turbine is less when compared to a steam turbine. The next advantage is smooth or low vibration, easy and fast operation so it is very good when used as a peaker power plant. The cost for investing in a gas turbine is lower than a steam turbine[4]. But the disadvantages of gas turbine is very low in efficiency, from $25 \%-30 \%$. This is because most of the turbine's work is used to drive the compressor. In an ideal calculation, according to literature[5], the work of turbine used to drive compressor is up to $50 \%$, but actually in the field almost $2 / 3$ of the turbine works. Another disadvantage is the sound is very noisy.

\section{B. Maintenance}

Maintenance is very important for the company. Not only for the company's operations but also the company's economy. Little maintenance and mayor maintenance still be carried out by a company. If the company not do regular maintenance of the machines or facilities that they have, then by time the machines or facilities that are available in the company will be damaged. It will be fatal and cause a large loss for the company. In an industry case study in the United States, companies that didn't do maintenance, will be $80 \%$ of their finances are absorbed in repairing damage to machinery, facilities and systems. But by implementing effective maintenance, it can eliminate failures and heavy damage to machinery, facilities and systems in the company and can save $40 \%-60 \%$ of company expenses[6]. In Indonesia, maintenance costs are also quite large. But the cost of damage because didn't do maintenance is larger. One example in the electricity industry, PT Indonesia Power Managing Director, Sripeni Inten Cahyani, explained the cost of maintaining electricity generation reaches $\mathrm{Rp} 2$ trillion per year. But with good routine maintenance can reduce these costs by $5 \%-10 \%[7]$.

\section{FMEA}

Failure Mode and Effect Analysis (FMEA) is a logic, structural analysis of a system, subsystem, device, or process. FMEA is one of the systems reliability and security analysis methods that are generally used to identify possible modes of failure, causes of failures, and consequences of such failures. Good and proper identification will increase overall product reliability and safety. In addition, there are many other objectives of using FMEA to identify and prevent safety hazards, minimize loss of performance from products and reduce performance, increase test and verification activities, improve process quality, be considered in product design and manufacturing processes, identify significant products and product characteristics, designing preventive maintenance plans and designing online diagnostic techniques[8]. The FMEA method converts qualitative to quantitative, then assess the risk of failure with the concept of utility functions as a basis for increasing priority order. The following steps are used to implement FMEA [9] are Severity Assessment, Occurrence Assessment, Detection Assessment and Risk Priority Number (RPN) calculation.

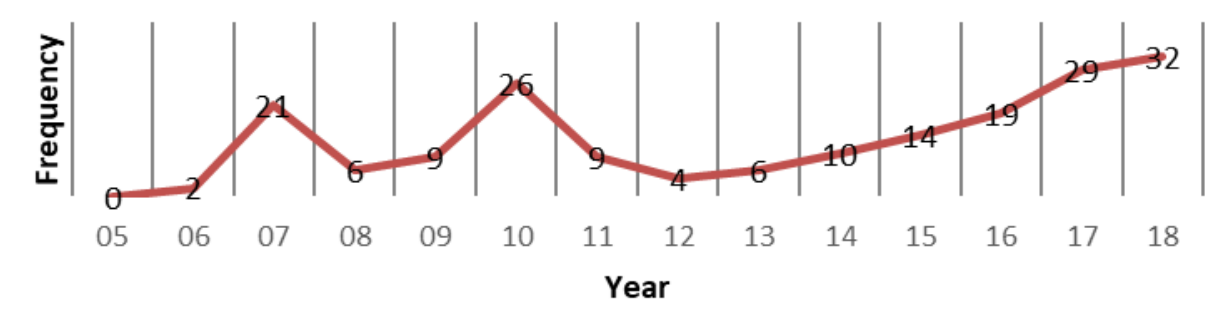

Figure 1. Frequency of start failure in PT.X

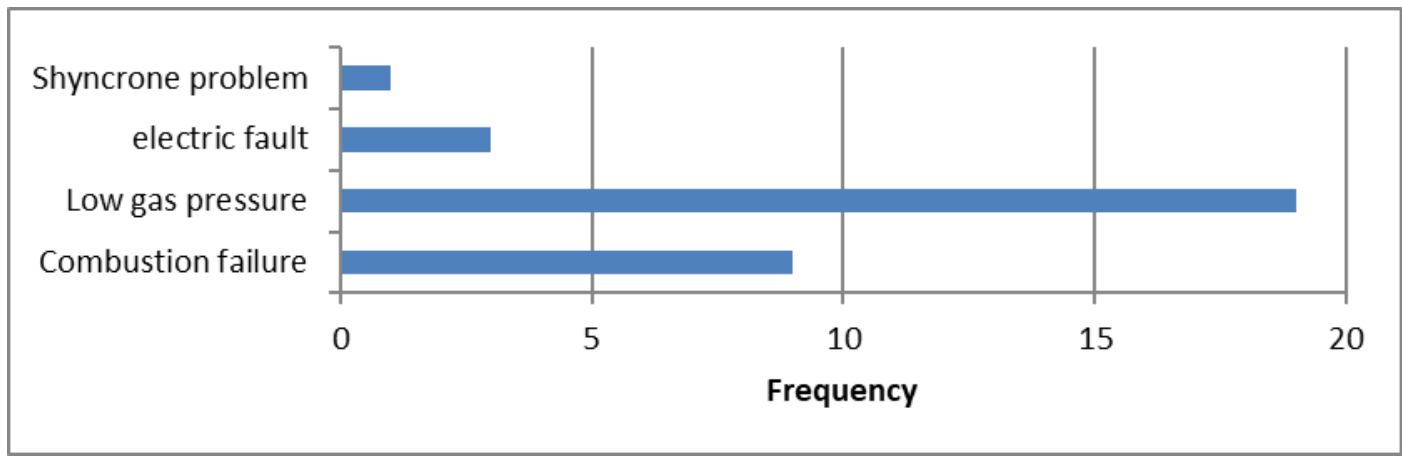

Figure 2. Frequency of start failure in PT.X depend of it caused. 


\section{RESEARCH METHODOLOGY}

The research methodology consist of several stages. They are data collection, data processing, data analysis and the stage of giving conclusion and recommendation. It is illustrate in Figure 3. At the data collection stage, there are two kinds of data, primary and secondary. Primary data will be carried out by brainstorming with experts in the operations, maintenance and engineering fields and secondary data from historical data reports of the gas turbine unit in the company. At the data processing stage, the data is carried out by assessing the risk of combustion failure using the FMEA method. First step is asking the expert to giving value of failure modes in severity, occurrence, and detection. For the severity category table, is as shown in table 1, for detection category is shown in table 2 and for occurrence category is shown in table 3. At the data analysis stage, an RPN assessment is carried out and a risk mitigation study is carried out with the highest RPN value. Because risks with high RPN values have an impact, the incidence and undetectable rates are high so it needs to be followed up so that it doesn't happen again. At the stage of giving conclusions and recommendation is make conclusions from the research and give recommendation to company and next researcher that will be studied next.

TABLE 4.

FAILURE MODES \& RPN VALUE

\begin{tabular}{llllll}
\hline \hline No. & Failure Mode & S & O & D & RPN \\
\hline 1 & Igniter abnormal & 4 & 4,3 & 4,1 & 71,0 \\
2 & Not fire & 3,6 & 4,1 & 4,4 & 65,5 \\
3 & System not detect fire & 2,9 & 4,4 & 4,6 & 57,8 \\
4 & Fuel valve sudden close & 3,3 & 4 & 3,6 & 46,9 \\
\hline \hline
\end{tabular}

\section{ANALYSIS \& RESULT}

From risk identification, there are four failure modes that caused combustion failure. After that, the failure modes assess with RPN value shown in Table 4. Igniter abnormal is a failure mode with the highest RPN value so this failure mode need to be mitigate the risk. From the analysis of the causes of igniter failures, several igniter failure indications are obtained, namely igniter not ignite, igniter not always ignite and igniter can ignite but with small fire. To mitigate this risk, the company that can do is always ensure the selector at the breaker igniter in auto conditions and then the company can measure current and voltage at the breaker and transformer igniter. It aims to determine the readiness and condition of the igniter. This measurement can determine the igniter's condition early if the power supply is lost, damage to the capacitor, transformer and connector cable, the condition of the igniter plug electrode whether in dirty condition or wear due to the age of use.

\section{CONCLUSSION}

From this research, there are four failure modes that cause combustion failure in the process of starting the gas turbine. Igniter abnormal, not fire, system not detect fire and the fuel valve suddenly close with an igniter abnormal failure mode is the highest RPN value. So the risk mitigation is for igniter abnormal failure mode is by carrying out activities to ensure the selector on the igniter breaker in auto condition and measuring the current and voltage on the igniter breaker and transformer. This activity will minimize the risk of combustion failure and provide potensial saving for the company.

\section{REFERENCES}

T. Taufik and A. Afrizal, "Evaluasi kinerja pemeliharaan PLTA dengan pendekatan maintenance scorecard dan Objective Matrix (OMAX) (Studi kasus unit pembangkit listrik tenaga air Maninjau)," J. Optimasi Sist. Ind., vol. 13, no. 1, pp. 561-574, Apr. 2016.

[2] M. P. Boyce, Gas Turbine Engineering Handbook, 2. ed. Oxford, UK: Butterworth-Heinemann, 2012.

[3] R. Sugiharto, "Perancangan Heat Recovery Steam Generator (HRSG) dengan Sistem Tekanan Uap Dua Tingkat Kapasitas Daya Pembangkitan 77 MW".," Universitas Sumatera Utara, 2009.

[4] L. O. M. A. Wahid, "Perbandingan biaya pembangkitan pembangkit listrik di Indonesia." 2006.

[5] T. E. Ekstrom, "Reliability/availability guarantees of gas turbine and combined cycle generating units," IEEE Trans. Ind. Appl., vol. 31, no. 4, pp. 691-707, 1995.

[6] B. S. Dhillon, Engineering Maintenance: A Modern Approach. Boca Raton, Florida : CRC Press, 2002.

[7] D. Abidin, "Biaya Pemeliharaan Pembangkitan Listrik Capai Rp 2 Triliun - Suaramerdeka.com Cyber News," Suara Merdeka.com, Semarang, 12-Oct-2018.

[8] C. Carlson, Understanding and Applying the Fundamentals of FMEAs. Arizona: ReliaSoft Corporation, 2014.

[9] S. B. Ambekar, A. Edlabadkar, and V. Shrouty, "A review: Implementation of failure mode and effect analysis," Int. J. Eng. Innov. Technol., vol. 2, no. 8, pp. 37-41, 2013. 